\title{
The Effect of Facies Changes on Hydrocarbon Production in Osisioma Field, Onshore, Niger Delta, Nigeria
}

\author{
Onyeanusi Peter Obinna ${ }^{1}$, Udoh Monday Udofia ${ }^{2}$, Imasuen I $\mathrm{O}^{1}$, Tsaku Stephen ${ }^{3}$, Omodolor Hope $\mathrm{E}^{1, *}$, \\ Aduomahor Benedict Oghenemaro ${ }^{1}$ \\ ${ }^{1}$ Department of Geology, University of Benin, P.M.B. 1154 Benin City, Edo State, Nigeria \\ ${ }^{2}$ Pioneer-Alfa Petroleum Services Ltd, Edo State, Nigeria \\ ${ }^{3}$ Reservoir Engineering services Department, IDSL, Edo State, Nigeria \\ *Corresponding author: hopeomodolor@gmail.com
}

\begin{abstract}
Detailed analyses of geological, petrophysical and seismic datasets were employed in other to determine the effect of facies change on hydrocarbon production. Static and dynamic modeling formed the terminal point for this integrated study of the $\mathrm{X}$ reservoir. Petrophysical properties that determine reservoir quality were measured. The average computed reservoir thickness, pay thickness, net pay thickness, net-to-gross (NTG), porosity and water saturation for the E1000X (Reservoir Name) reservoir zone was $114.4 \mathrm{~m}, 55.4 \mathrm{~m}, 42.6 \mathrm{~m}, 74 \%, 21 \%$ and $25 \%$ respectively with no significant variation. The original hydrocarbon-in-place of the reservoir was also evaluated base on mean weighted averages of porosity, water saturation, and gross rock volumes and net-to-gross ratios. Fluid types was used to define the reservoir on the basis of neutron/density log signatures which may be basically water, oil and gas. Stratigraphic model was built and correlation panel generated. This in-turn was used to delineate the facies types across the interpreted $\mathrm{X}$ reservoir. The output from the facies using an acceptable global flow zone indicator (FZI) was used to model the permeability from the petrophysical analysis. Also static model was built where surfaces from seismic interpreted model was used to build a static model in other to generate geological parameters for the dynamic model simulation. In the dynamic model phase of this study, it was observed that wells placed in the channel dominated facies had better oil production performance followed by wells placed in the Shorface facies environment and least by wells placed in heterolitics environment. The prediction phase of the six wells within the 20 years period in the E1000X reservoirs shows that channels and Shoreface dominated facies gives better production performance over the production life of the wells.
\end{abstract}

Keywords: Niger Delta stratigraphy, petrophysical property, static and dynamic model, facies environment

Cite This Article: Onyeanusi Peter Obinna, Udoh Monday Udofia, Imasuen I O, Tsaku Stephen, Omodolor Hope E, and Aduomahor Benedict Oghenemaro "The Effect of Facies Changes on Hydrocarbon Production in Osisioma Field, Onshore, Niger Delta, Nigeria.” Journal of Geosciences and Geomatics, vol. 6, no. 2 (2018): 35-40. doi: 10.12691/jgg-6-2-1.

\section{Introduction}

The Osisioma oilfield is located in the Eastern part of Niger Delta sedimentary basin. The environment of deposition is mainly coastal deltaic to shallow marine comprising of shoreface and channel facies. Identifying and modeling key reservoir complexities caused by different environment of deposition (EOD) and effect of this on production performance in Niger Delta oil wells is the concern for this project. One of the key elements is facies architecture. Failure to adequately model reservoir facies architecture even in high porosity and permeability reservoirs can lead to overly simply static/dynamic models and lead to forecasting errors. This project will discusses the impact of the Osisioma $\mathrm{X}$ reservoir facies modeling on the reservoir performance prediction. The reservoir facies model was more accurate because it incorporated rock type variogram across the field and associated reservoir connectivity. The reservoir facies model was scaled-up and used for dynamic simulation of the $\mathrm{X}$ reservoir where its effect on production performance was analyzed during oil field production performance prediction in the dynamic phase. This study therefore seek to integrate petrophysical parameters, seismic surfaces, and static model output data into dynamic simulation model in other to determine the effect of changes in facies distribution on hydrocarbon production in "Osisioma" oilfield, Niger Delta.

This independent study is limited to the inference of reservoir facies analysis, petrophysical trend and static data of the reservoir.

\subsection{Location and Geology of the Study Area}

The study area is located within Niger delta, Southern Nigeria (Figure 1). The Niger Delta sedimentary environment is a prolific petroleum province and it covers an area defined 
by latitude $3^{\circ} .6^{\circ}$ Nand longitude $5^{\circ} .8^{\circ} \mathrm{E}$ with an overall regressive elastic sediment thickness of about $12 \mathrm{~km}$ [5].

\subsection{Geology and Stratigraphic setting of the Niger Delta}

The Niger Delta, on the passive western margin of Africa, has been described as a classic example of continental-margin structural collapse under sediment loading [6,7]. It ranks amongst the most prominent and prolific petroleum producing deltas in the world, it accounts for about $5 \%$ of the world's oil and gas reserves and about $2.5 \%$ of the present-day basin area on earth $[10,11]$. The Niger Delta sedimentary basin was initiated in the Early Tertiary times $[2,3,11,12]$.

It occupies the Gulf of Guinea continental margin in equatorial West Africa. This basin occupies a total area of about $7,500 \mathrm{~km}^{2}$ in the Gulf of Guinea with a sediment thickness up to $12,000 \mathrm{~m}$ [1], documented that the sedimentary basin of the Niger Delta encompasses a much larger extent region than the modern delta constructed by the Niger - Benue drainage system [9]. This includes the Cross River delta and further extends eastwards into the continental margins of neighboring Cameroon and Equatorial Guinea sub-environments. The sedimentary wedge of the Niger Delta contains a major submarine part [9] which forms part of the complex continental margin intruding into the Gulf of Guinea (Figure 2).

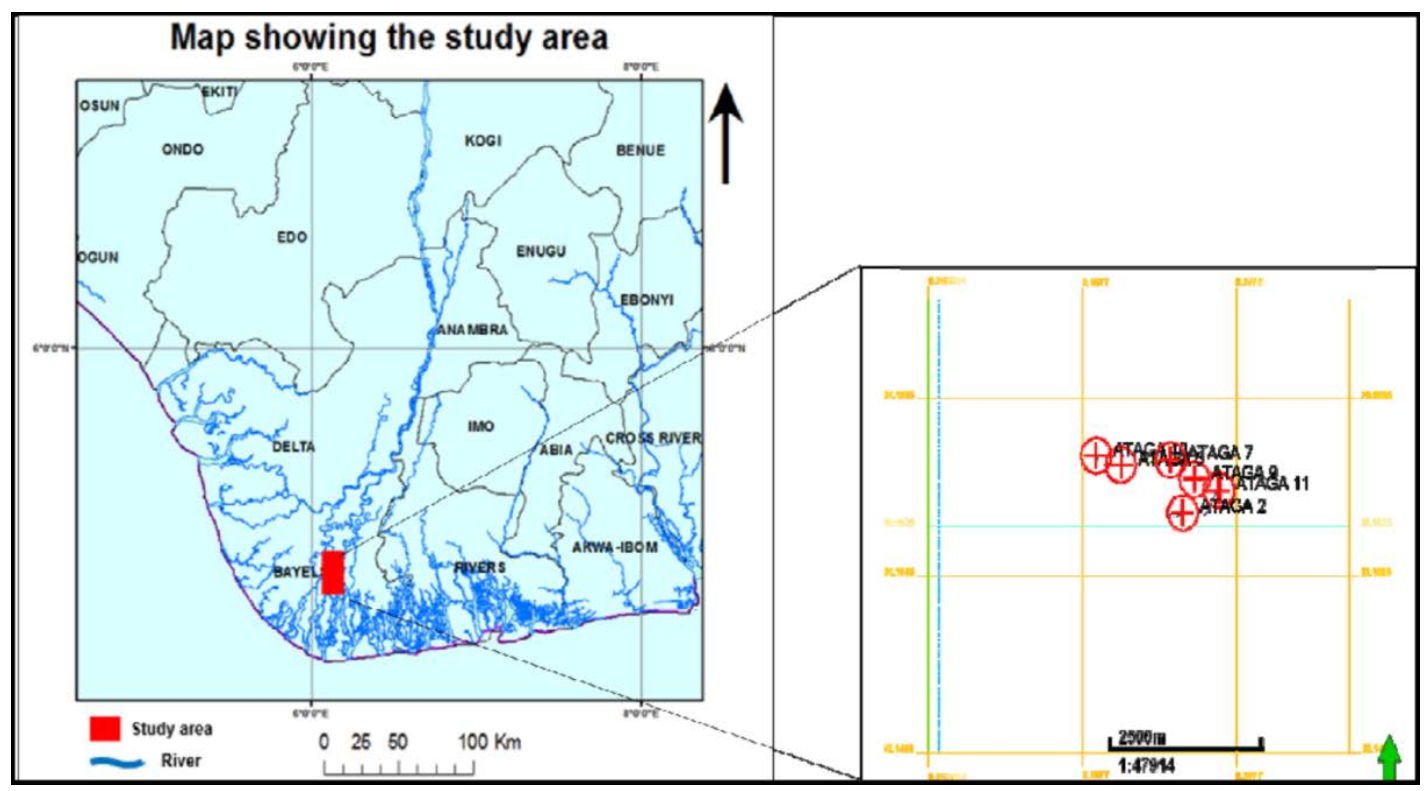

Figure 1. Location and base map of the study area

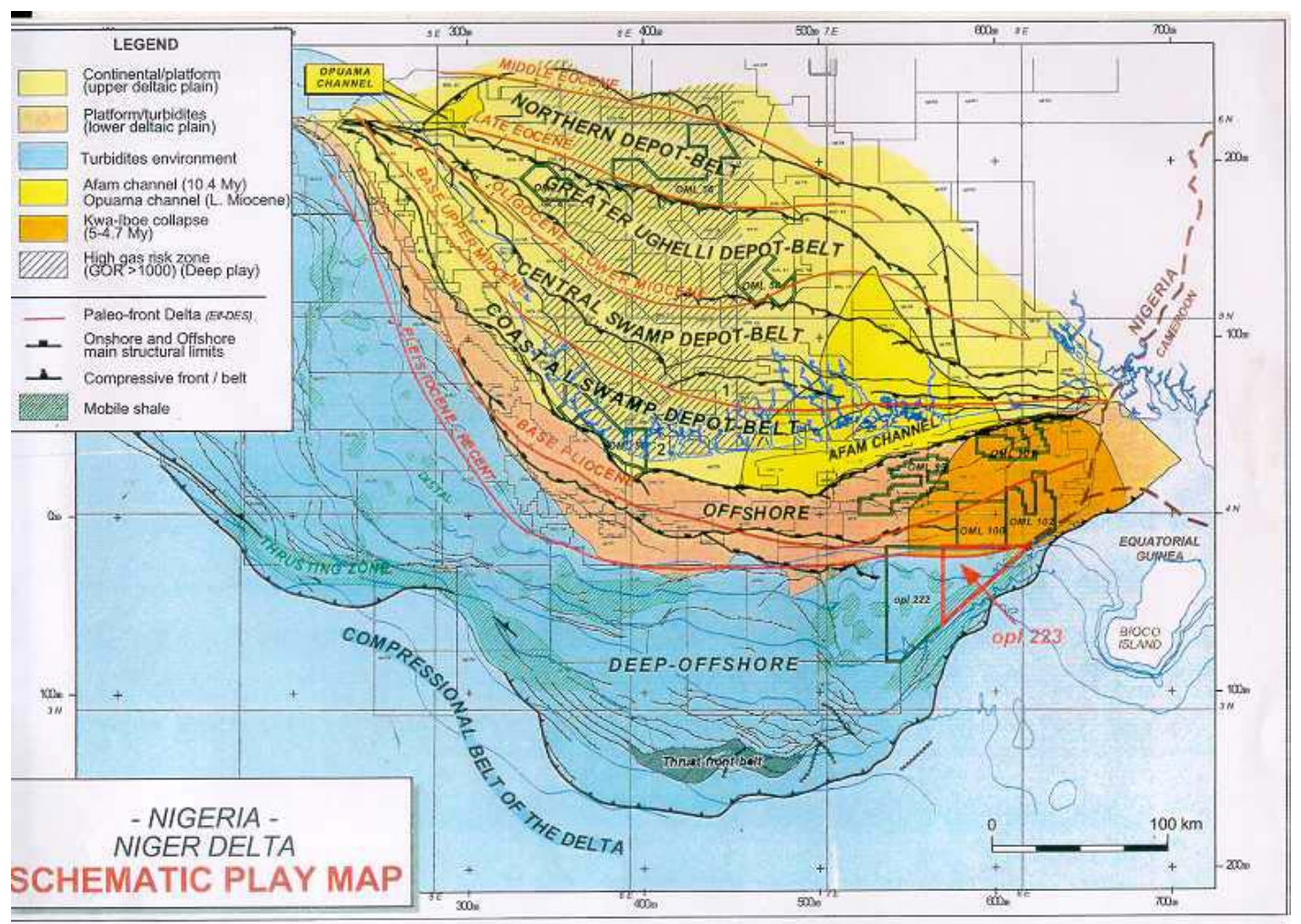

Figure 2. Paleogeography of Tertiary Niger Delta [4] 


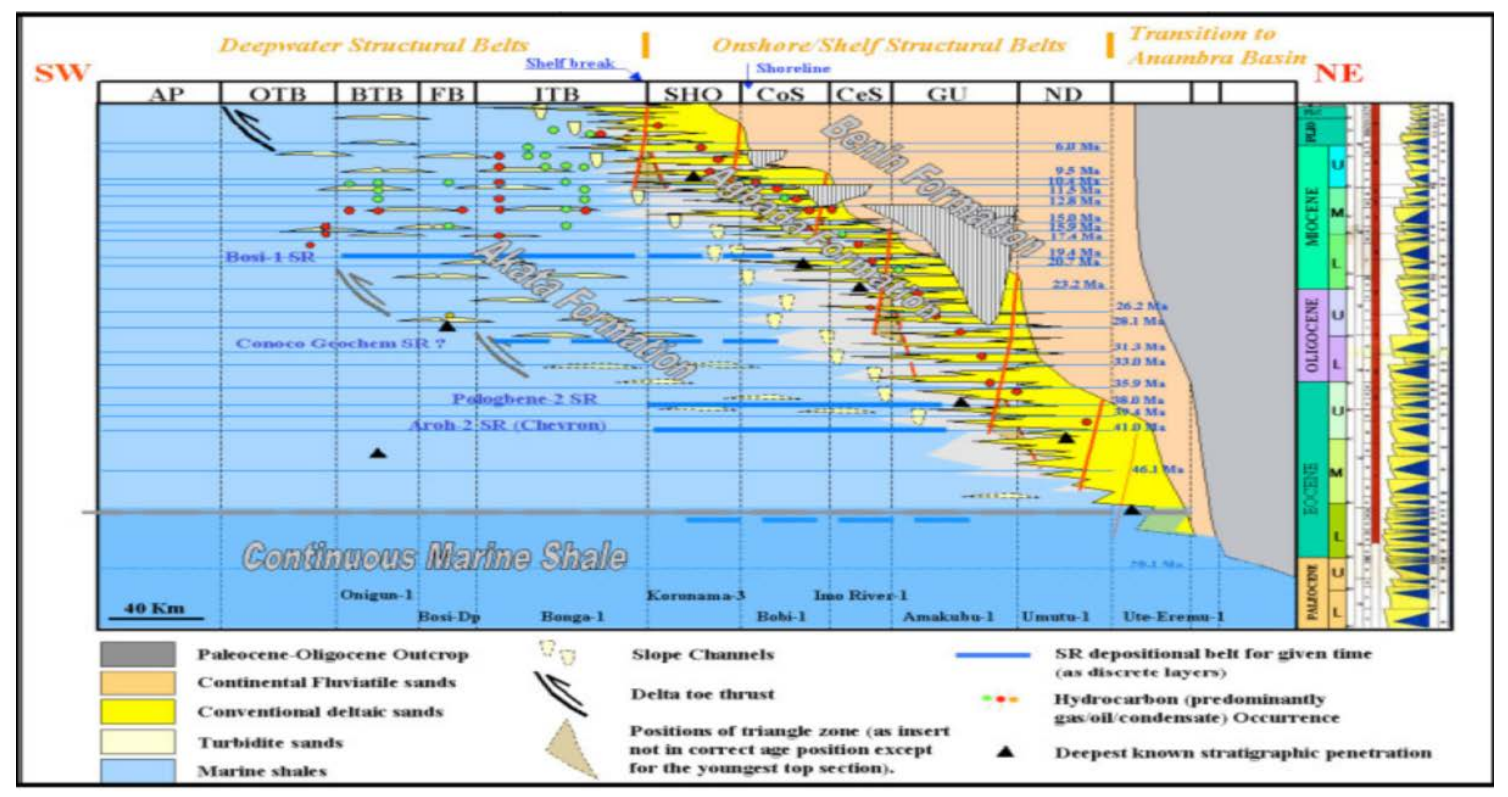

Figure 3. Stratigraphic column of Niger delta [4]

\section{Materials and Methods}

Seismic surfaces, fault polygon, well logs datasets from six (6) wells in Osisioma field were provided by SPDC, Port Harcourt for this study and were interpreted using PowerLog software for Petrophysics modeling and analysis, Petrel software for Static Modeling and Dynamic modeling. Gamma ray (GR), neutron porosity (NPHI) and bulk density (RHOB) logs were integrated to delineate non-reservoir rock from reservoir rock and resistivity (ILD) logs was interpreted to differentiate between the formation fluids (hydrocarbon or water) within the reservoir intervals. Integration of neutron porosity (NPHI) and bulk density (RHOB) logs were interpreted to discriminate between hydrocarbon types (gas or oil) within the reservoir. Environments of deposition was interpreted based on facies analysis of gamma ray log motifs and standard formulae were used to estimate petrophysical parameters; gross reservoir thickness, net reservoir thickness, porosity and water saturation from logs data. The interpreted faults and surfaces were input to build a 3D skeleton grid for the static model. The area extent of the model $\left(10.54 \mathrm{~km}^{2}\right)$ was defined by the limit of anticlinal and fault supported structural closure and geostatistical algorithm (Sequential indicator simulation and Sequential Gaussian simulation) to populate the structural model with upscaled facies which were mainly Chanel, Upper shoreface, Lower shoreface and Heterolitics Lithofacies were distributed across the structural model to depict the interpreted subsurface facies distribution and was used to constraint the distribution of petrophysical properties (net to gross, porosity and water saturation) within the model Stock tank oil initially place (STOIIP) for E1000X-reservoir

$$
N=7758 A h \phi(1-S w) / \text { Boi9 }
$$

Where;

$N=$ Stock tank oil and gas initially in place STOIIP (STB) $7758=$ Conversion factor from acre-ft to bbl

$A=$ Area of reservoir (acres) obtained from map and model

$h=$ Reservoir pay thickness (ft) $\emptyset=$ Reservoir porosity

$S \mathrm{w}=$ Water saturation

Boi $=$ formation volume factor for oil at initial conditions (reservoir bbl/stb) and was taken as 1.0bbl/stb.

The dynamic models was built to capture the heterogeneities in the dynamic phase of the reservoirs, using the static data as an input into the model to study the effect of facies changes on production performance of the existing wells that have produced from the wells and prediction of the infill wells performance. Pressure Volume Temperature (PVT) of the E1000X (Reservoir Name) reservoir was analyzed using standard correlation to which "Standing correlation" was adopted as it gives the least standard deviation error. In the absence of Special Core Analysis Lab Data (SCAL) data, the capillary pressure data used in the models were derived from industry algorithm that uses saturation height functions estimated from petrophysical data with respect to permeability classes for each model. This algorithm outputs Corey exponents and residual water saturation needed to generate the relative permeability curve for each set of permeability group and also the capillary pressure tables. The dynamic models were calibrated against measured (historical) well performances. The Stock tank oil and gas initially in place from the static and calibrated dynamic models was also generated. Existing well production was historically matched and future well prediction of individual wells was carried out.

\section{Results and Discussion}

The E1000X (Reservoir Name) reservoirs were delineated and correlated across Osisioma wells based on well logs interpretation; however, this project focused on reservoir characterization of E1000X - reservoir. Gamma ray logs motifs trends were applied to E1000X -reservoir to interpret its dominant facies. An increase in gamma ray value depicts upward trend (fining upward sequence) with sharp base and was observed from all the wells in Osisioma field for E1000X - reservoir. However, this suggests that E1000X - reservoir is becoming clay-rich 
upwards and may be interpreted as a fluvial, tidal channel and mixture of distributary channel environments overlain on a basal Upper shoreface depositional environment which shows a decrease in gamma ray value with an overall coarsening upward sequence trend as presented in Figure 4. In this study, the E1000X - reservoir zone was evaluated for its reservoir thickness, pay thickness, net to -gross, porosity, water saturation and the result is presented in Table 1. However, the reservoir thickness for across the six wells ranges from 45 to 84 Subsea True Vertical Depth (SSTVD) while the pay thickness ranges from 27 to 79 Subsea True Vertical Depth (SSTVD) with good porosity and net-to- gross of $18-29 \%$ and $63-85 \%$ respectively. Water saturation of ranges $(18-49 \%)$ within this zone reflects relative good hydrocarbon accumulation within the reservoir. Furthermore, Table 1 below reveals the statistical evaluation of the encountered petrophysical properties of the analyzed well in this study.

A corresponding and noticeable deduction in the resistivity was observed which have intensively caused invariably reduction in the overall pay thickness. It is however suggested that this zone may contain pyritized and/or clay minerals which causes the perceptible low resistivity. The result of E1000X reservoir (Figure 6) facies modelling indicate high sand to the shale proportion, this conform to the geologic knowledge of most reservoir in Niger Delta, which is sand rich with shale intercalations. Apart from having a good structural closure as seen on the depth structure map, the facies model of E1000X reservoir shows that, E1000X - reservoir is rich in sand content. Facies model for E1000X - reservoir was used to constrain the distribution of the petrophysical properties (net-to-gross, porosity and water saturation) as shown in Figure 6.

The Osisioma E1000X reservoir model was initialized under hydrostatic equilibrium method and the volume compared to the static volume is compared as shown in Table 2. This was carried out using PETREL RE software, no reservoir up-scaling was done to cut off the aquifer volume to avoid distorting the reservoir characteristic.

History match was carried out on the existing wells that has production as shown in Figure 5.

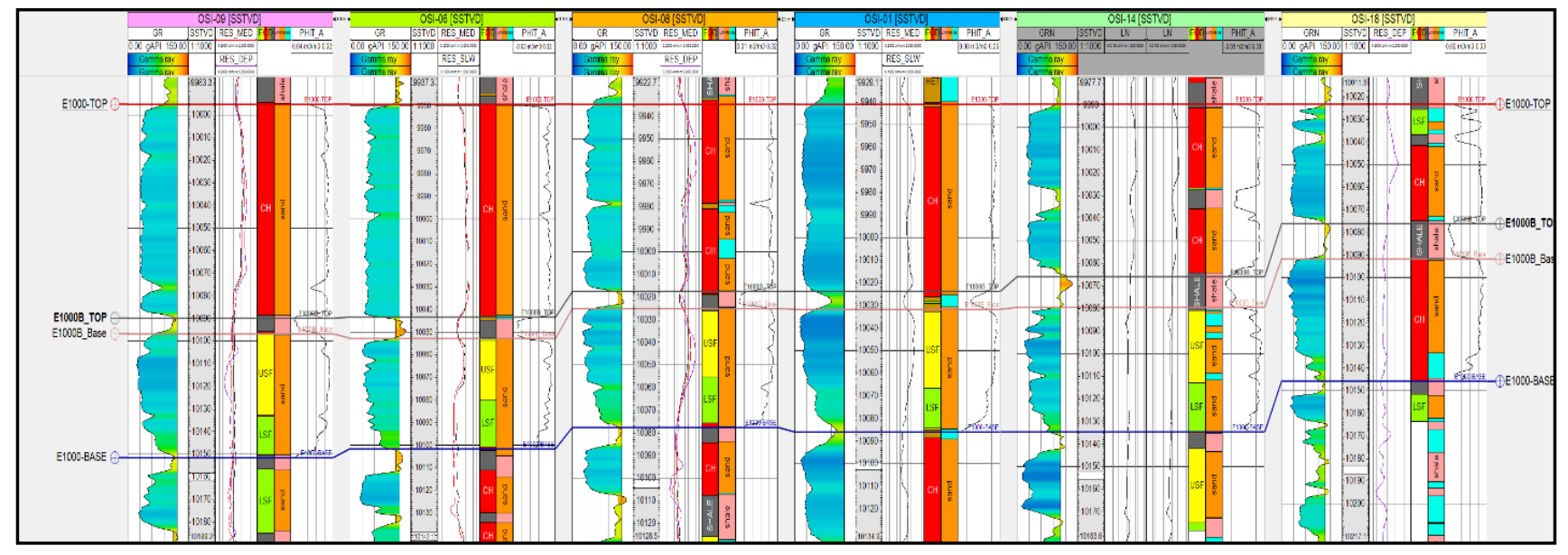

Figure 4. Lithology Correlation of six wells in Osisioma Field

Table 1. Petrophysical properties of E1000X reservoir, Measured Depth (MD), Hydrocarbon Ore Volume height (HPVH), Water saturation (SW), Total Porosity (PHT), Volume of Shale (VSALE), Total Water Saturation (SWT), Million Stock Tank Barrels (MMSTB)

\begin{tabular}{|c|c|c|c|c|c|c|c|c|c|c|c|c|}
\hline S/NO & $\begin{array}{l}\text { Zone } \\
\text { name }\end{array}$ & $\begin{array}{c}\text { Well } \\
\text { name }\end{array}$ & $\begin{array}{c}\text { Top } \\
\text { depth(MD) }\end{array}$ & $\begin{array}{c}\text { Bottom } \\
\text { depth(MD) }\end{array}$ & $\begin{array}{c}\text { Gross } \\
\text { interval }\end{array}$ & $\begin{array}{l}\text { Net Pay } \\
\text { inte Avg }\end{array}$ & $\begin{array}{c}\text { Pay/Gross } \\
\text { Ratio } \\
\end{array}$ & Phi(pay) & HPVH(Pay) & $\begin{array}{c}\text { Net Res } \\
\text { int }\end{array}$ & $\begin{array}{c}\text { Avg } \\
\text { Phi(Res) } \\
\end{array}$ & \\
\hline 1 & E1000X & Osi-01 & 9941 & 10025 & 84 & 78.25 & 0.932 & 0.285 & 17.297 & 78.25 & 0.285 & 0.226 \\
\hline 2 & E1000X & Osi-05 & 9969 & 10002 & 33.7 & 32.5 & 0.964 & 0.185 & 6.724 & 32.5 & 0.354 & 0.185 \\
\hline 3 & E1000X & Osi-06 & 9961 & 10008 & 46.8 & 47.79 & 0.995 & 0.235 & 9.213 & 47.79 & 0.253 & 0.237 \\
\hline 4 & E1000X & Osi-08 & 9955 & 10001 & 46.1 & 46.1 & 0.626 & 0.205 & 9.603 & 46.06 & 0.262 & 0.205 \\
\hline 5 & E1000X & Osi-09 & 10023 & 10065 & 43.4 & 42.36 & 0.258 & 0.237 & 8.326 & 42.36 & 0.58 & 0.258 \\
\hline 6 & E1000X & Osi-25 & 9930 & 9975 & 45.9 & 27 & 0.589 & 0.226 & 5.063 & 45.85 & 0.234 & 0.49 \\
\hline
\end{tabular}

\begin{tabular}{|c|c|c|}
\hline \multicolumn{3}{|c|}{} \\
\hline S/NO & Parameter & Cut-off \\
\hline 1 & PHT & 0.15 \\
\hline 2 & VSALE & 0.5 \\
\hline 3 & SWT & 0.6 \\
\hline
\end{tabular}

Table 2. E1000X reservoir volumes

\begin{tabular}{|c|c|c|c|}
\hline \multirow{2}{*}{ Reservoir/Sand } & Static Model & \multicolumn{2}{|c|}{ Dynamic Model } \\
\cline { 2 - 4 } & STOIIP (MMstb) & Dissolved GIP (Bcf) \\
\hline E1000X & 80.25 & 78.9 & 56.0 \\
\hline
\end{tabular}


However, the wells were carried to production prediction phase to determine the production performance of each wells in different facies types. The saturation maps before and after prediction is shown in Figure 6.

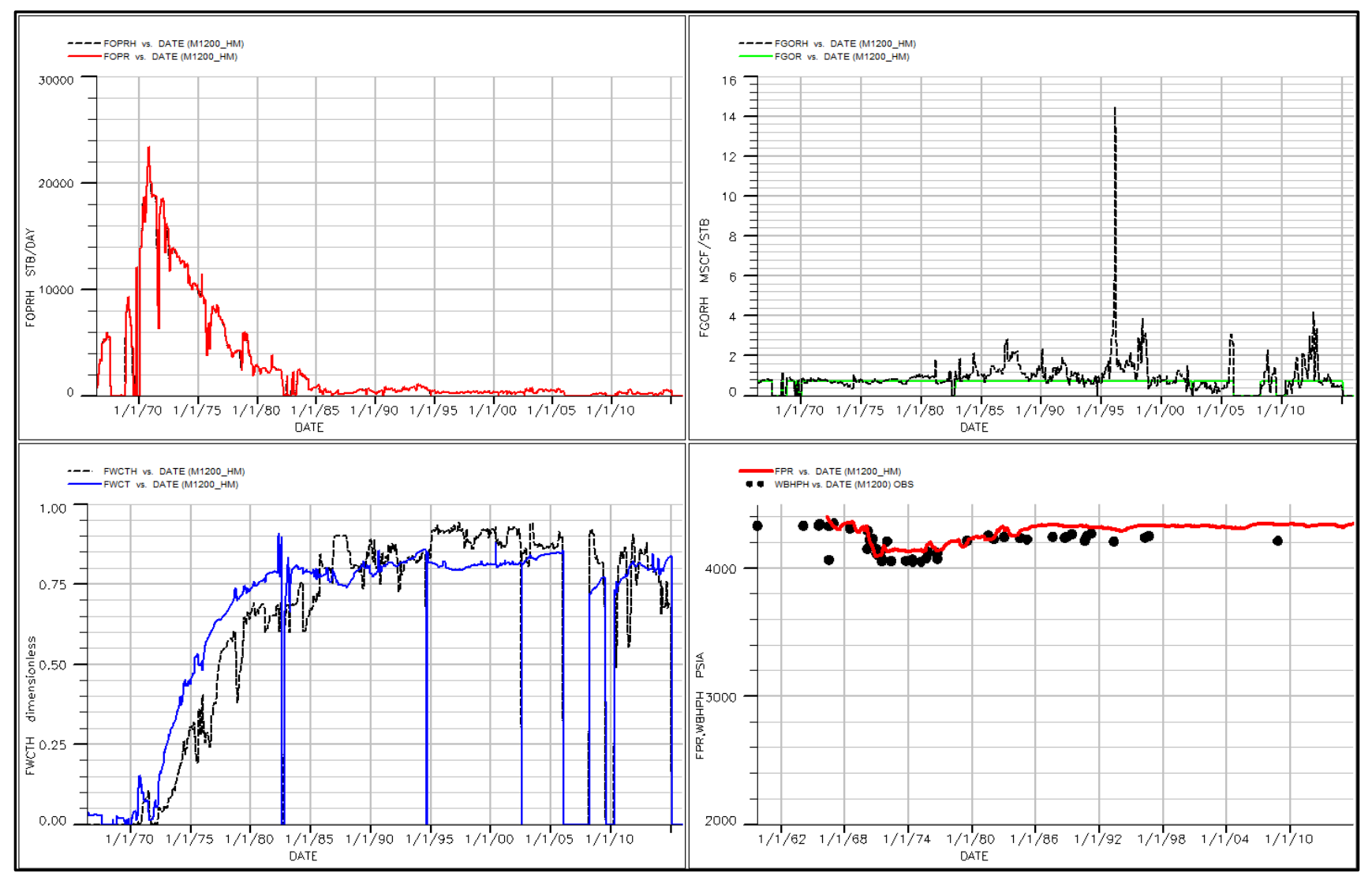

Figure 5. Osi-6 Prediction Performance Plot

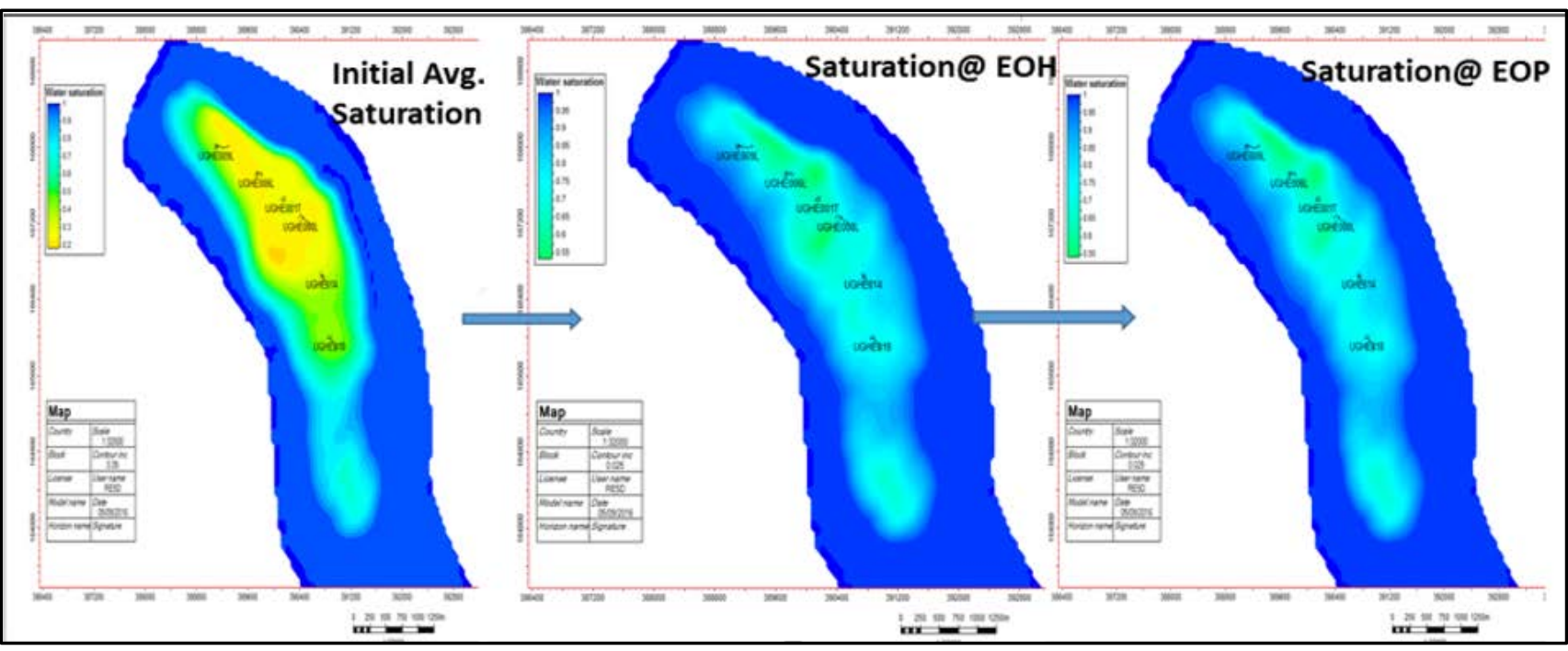

Figure 6. Osisioma E1000X Saturation Maps

Table 3. E1000X wells cumulative production. Lower Shore faces (LSF), Upper Shore Faces (USF) and Channels Sand (CH)

\begin{tabular}{|l|l|l|l|l|}
\hline RESEVOIR & STOIIP & WELL NAME & FACIES TYPE & CUM.OIL PROD MMstb \\
\hline & & Osi-OO8L & CH & 25 \\
\hline & & Osi-OO9L & USF & 4.14 \\
\hline & & Osi-OO6L & CH & 9.7 \\
\hline X1000X & 78.9 & Osi-OO5L & LSF & 1.81 \\
\hline & & Osi-OO18L & LSF & 0.54 \\
\hline & & Osi-OOO1L & USF & 5 \\
\hline & & TOTAL & & 46.86 \\
\hline
\end{tabular}


The production prediction spanned through 20 years period forecast and the cumulative production from each wells were tabulated as seen Table 3. A constant constraint was placed on each of the well throughout the prediction life of the wells. The wells placed in channel sand had better production performance over the 20 years prediction period compared to shoreface and heterlotics.

\section{Conclusion}

The lithology encountered within the E1000X reservoir zone comprises of predominantly sand and shale with intercalation silts. The encountered facies within the wells comprises of channels, barrier bars complexes, deltamarine fringes and restricted mudstones.

However, the environments of deposition/facies delineated in this study consist of channels, shoreface sands (upper and lower shorefaces), heterolithics and shales. These depositional settings were identified from log motifs based on their smooth/cylindrical, (erosional base), funnel and bell shapes respectively. Channel sands are cylindrical, blocky,serrated and in some cases have fining upward pattern at their tops and their readings ranges from 20-70[g(API)] and they have flat bases. The Upper shoreface sands on the other hand are blocky with reading range of 30 - 60[g(API)]. Conversely, lower shoreface sands have a coarsening upward sequence pattern and sometimes exhibited a 45 - 90[g(API)] range readings. The shales are either marine shales or Coastal plain shales, their reading ranges from >100 - 150 [g(API)] while heterolithics deposits (almost equal propositions of sand and shale) reading ranges from $<100[\mathrm{~g}(\mathrm{API})]$. The average computed reservoir thickness, pay thickness, net pay thickness, NTG, porosity and water saturation for the E1000X-reservoir zone was $114.4 \mathrm{~m}, 55.4 \mathrm{~m}, 42.6 \mathrm{~m}, 74 \%$, $21 \%$ and $25 \%$ respectively. The prediction phase of the six wells within the 20 years period in the E1000X reservoirs shows that channels and Shoreface dominated facies gives better production performance over the production life of the wells.

\section{References}

[1] Beka, F. T., \& Oti, M. N. (1995). The distal offshoreNiger Delta: frontier prospects of a mature petroleum province, In M. N Oti and G. Postma (eds.), Geologyof Deltas: Rotterdam, A.A. Balkema, pp. 257-267.

[2] Doust, H., \& Omatsola, E. (1989). Niger Delta, In Divergent passive margin basins, J.D. Edwards and P.A. Santogrossi, (eds.), American Association of Petroleum Geologists Memoir, 48, 201-238.

[3] Edwards, J.D., \& Santogrossi, P.A. (1990). Summaryand conclusions, In, J.D Edwards and P.A Santogrossi (eds.), Divergent/passive Margin Basins, AAPG Memoir 48: Tulsa, 239-248.

[4] Ejedawe, J.E. (1981). Patterns of Incidence Of Oil Reserves in Niger Delta Basin.American Associatioin of Petroleum Geologists Bulletin 65, 1574-1585.

[5] Evamy, B.D., Haremboure, J., Kamerling, P., Knaap, W.A., Molloy, F.A., \& Rowlands, P.H. (1978). Hydrocarbon habitat of Tertiary Niger Delta, American Association of Petroleum Geologists Bulletin. 62, 277-298.

[6] Journel, A. J., \& Huijbregts, C. J. (2003). Mining Geostatistics. The Blackburn Press, New York, 56-107.

[7] Kulke, H., (1995): Regional Petroleum Geology of the World. Part II: including Africa. Berlin, Gebrüder Borntraeger, p. 143-172

[8] Oyedele, K. F., Ogagarue, D. O., \& Mohammed, D.U. (2013). Integration of 3D Seismic and Well log Data: In the Optimal Reservoir Characterization of EMI Field, Offshore Niger Delta Oil Province, Nigeria. American Journal of Scientific and Industrial Research, 4(1), 11-21.

[9] Reijers, T. J. A., S.W. Petters, and C.S. Nwajide, 1997. The Niger Delta Basin,In: R.C. Selley, (ed.). Africa Basins - Sedimentary Basin of the World 3: Amsterdam, Elsevier Science, pp. 151-172.

[10] Robert, R., and Howard, R, (1989): A history on mapping of the subsurface structure, p. 1371-1383. Published online November 1 , 1989.

[11] Stacher, P. (1995). Present Understanding of the Niger Delta hydrocarbon habitat, In, M. N Oti and G. Postma (eds.), Geology of Deltas: Rotterdam, A.A. Balkema, 257-267.

[12] Weber, K. J. (1987). Hydrocarbon Distribution Patterns in Nigerian Growth Fault Structures Controlled By Structural Style and Stratigraphy. Journal of Petroleum Science and Engineering, 1, 91-104. 